incomprehension has been interpreted as the reflection of a fundamental opposition between science and faith." Goodwin's Galileo refers to this mutual incomprehension when he tells Urban, "I thought you understood, but you do not understand. My philosophy rests on faith. I have been gifted by God to understand some of the language of His creation."

Goodwin beautifully dramatizes the two men's inability to reconcile by using on stage a piece of scientific equipment. Galileo demonstrates his occhiale - a compound microscope, a modification of his telescope to the delighted Pope. Several scenes and many years later, the Pope picks up the same occhiale to let the scientist examine a communion wafer under its lens. Although Galileo admits he sees only an uneven surface, resembling that of the Moon, he accepts on faith the wafer as the body of Christ. The Pope accuses Galileo of being a heretic, "one who misreads the faith", and "the creator of a whole new faith whose trinity is the eyes ... the mouth ... and the brain".

Goodwin's earlier career as a speech writer for US presidents John F. Kennedy and Lyndon Johnson has clearly familiarized him with the loneliness of political leaders. At the end of the play, it is the victorious Pope who is more bereft than Galileo. Compelled by the responsibility of his office, Urban has jettisoned not only Galileo but also his own oldest friend, Monsignor Giovanni Ciampoli, who, as secretary of the briefs, gave Galileo "the licence to unloose his pestilential work on enfeebled Europe". Urban banishes Ciampoli to a remote village.

Galileo, deprived of the companionship of his daughter who has predeceased him, is joined in the final scene by Father Benedetto Castelli, a former student of Galileo and now a professor. Castelli's return restores hope to his former teacher, whose forced recantation has left him wondering: "How shall I continue - my proclamations of new wonders returned only by mocking echoes from the indifferent hills of Tuscany." As the two men set off for Arcetri, near Florence, where Galileo will be confined for the rest of his life, the older man tells his disciple, "Let us go home. There is much for us to do."

Throughout the play, the language and stage business were enhanced through the motifs of burning, revolution and rotation. The powerful opening scene depicts philosopher Giordano Bruno being burned at the stake in Rome's Campo dei Fiori in 1600 for heresy. Later, Maria burns Galileo's papers, as per her father's request. Goodwin used large, horizontally rotating devices on stage to demonstrate some of Galileo's scientific insights to great effect.

Following its brilliant run in Boston, Two Men of Florence deserves to find its place as a standard in the growing repertoire of plays dealing with science and scientists, including Bertolt Brecht's Life of Galileo and Michael Frayn's Copenhagen.

Jay M. Pasachoff is director of the Hopkins Observatory, Williams College; Naomi Pasachoff is a research associate at Williams College, Williamstown, Massachusetts 01267, USA. e-mail: jay.m.pasachoff@williams.edu; naomi.pasachoff@williams.edu

\title{
Smells like green spirit
}

\section{Green Aria: A ScentOpera \\ The Peter B. Lewis Theater, Guggenheim Museum, New York City \\ 31 May and 1 June 2009}

Audience members attending Green Aria, which has its world premiere at the Guggenheim Museum in New York this week, can leave their opera glasses at home. The brainchild of director and librettist Stewart Matthew, this aria will be performed in the dark. But while the eyes get a rest, the nose will be hard at work. Green Aria is a scent opera, a performance involving synchronized sounds and smells.

Each of the roughly two dozen characters in this musical tale about humanity's attempt to tame nature will have a distinct odour, transmitted for a few seconds at a time through a 'scent speaker' attached to each auditorium chair. The opera will tap into two perceptual pathways in the brain simultaneously.

"There have been other attempts to introduce smell technology in conjunction with various forms of art and entertainment," explains Matthew. But it is little used today. In 1960, a system called Smell-O-Vision released timed scents in a cinema to match the scenes unfolding in a film. And a 1981 movie by John Waters, Polyester, prompted audiences to use scratch-and-sniff Odorama cards at particular points in the plot.

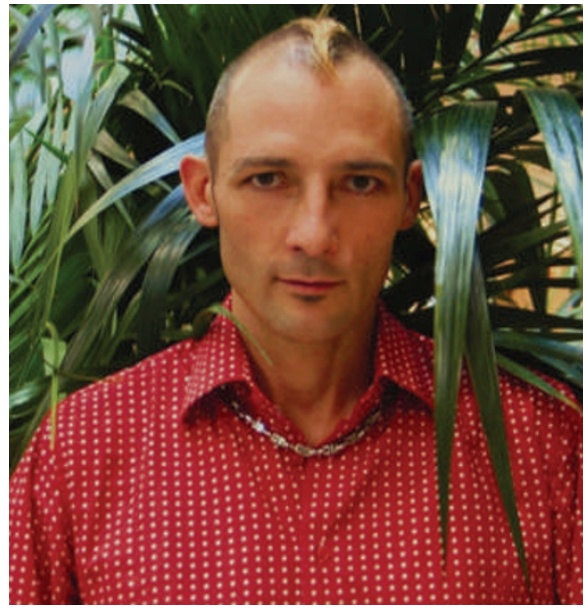

Perfume perfectionist Christophe Laudamiel.

In the Guggenheim Museum's theatre, special tubing will connect the scent speakers on the chairs to a customized 'odour organ' jointly developed by Fläkt Woods, a company specializing in air-circulation systems, and Aeosphere, a fragrance media company. Aeosphere is headed by Matthew and fragrance designer Christophe Laudamiel, who created the opera's scents.

Laudamiel holds a master's degree in chemistry and has taught at both Harvard University and the Massachusetts Institute of Technology in Cambridge. He took pains to ensure that the voices in the opera have appropriately matched scents. For example, the fragrance of one character, Crunchy Green, is made up of ingredients that include a leafy-smelling chemical and a rooty scent known as gentian absolute, derived from gentian plants that grow on dormant volcanoes in France.

The unconventional music of the opera written by composers Nico Muhly and Valgeir Sigurðsson - does not contain words but consists instead of sung sounds, notes played by orchestra instruments and electronic elements. When the music calls for a chord of voices, the scent speakers, too, release a 'chord' of corresponding odours.

Laudamiel notes that the team had to consider human biology when constructing the piece. Specifically, the succession of sounds and scents needed careful arrangement - a person can quickly become accustomed to one scent, such that it loses its impact if there is no variation. Moreover, "the perception of scent number two is going to depend on scent number one", he adds.

Stewart doesn't bar the possibility of someday wearing one of the scents developed for Green Aria in public, but explains that they would need fine-tuning. "The intent is to compose the scents for the opera. If there is a potential to apply the scents to the skin, that's a secondary consideration."

Roxanne Khamsi is news editor for Nature Medicine in New York. 